Chapter 2

\title{
Tabular Data and Graphical Images in Support of the U.S. Geological Survey National Oil and Gas Assessment - The Wind River Basin Province
}

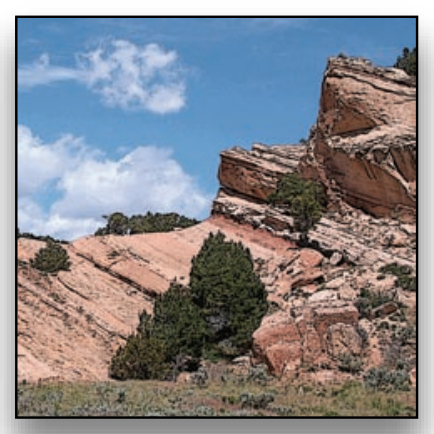

Click here to return to Volume Title Page

By T.R. Klett and P.A. Le

Chapter 2 of

Petroleum Systems and Geologic Assessment of Oil and Gas in the Wind River Basin Province, Wyoming

Compiled by USGS Wind River Basin Province Assessment Team

U.S. Geological Survey Digital Data Series DDS-69-J 


\section{U.S. Department of the Interior \\ DIRK KEMPTHORNE, Secretary}

\section{U.S. Geological Survey \\ Mark D. Myers, Director}

\section{U.S. Geological Survey, Reston, Virginia: 2007}

For product and ordering information:

World Wide Web: http://www.usgs.gov/pubprod

Telephone: 1-888-ASK-USGS

For more information on the USGS - the Federal source for science about the Earth, its natural and living resources,

natural hazards, and the environment:

World Wide Web: http://www.usgs.gov

Telephone:1-888-ASK-USGS

Any use of trade, product, or firm names is for descriptive purposes only and does not imply endorsement by the U.S. Government.

Although this report is in the public domain, permission must be secured from the individual copyright owners to

reproduce any copyrighted materials contained within this report.

Suggested citation:

Klett, T.R., and Le, P.A., 2007, Tabular data and graphical images in support of the U.S. Geological Survey national oil and gas assessment-The Wind River Basin Province in USGS Wind River Basin Province assessment team, Petroleum systems and geologic assessment of oil and gas in the Wind River Basin Province, Wyoming: U.S. Geological Survey Digital Data Series DDS-69-J, ch. 2, $16 \mathrm{p}$. 


\section{Contents}

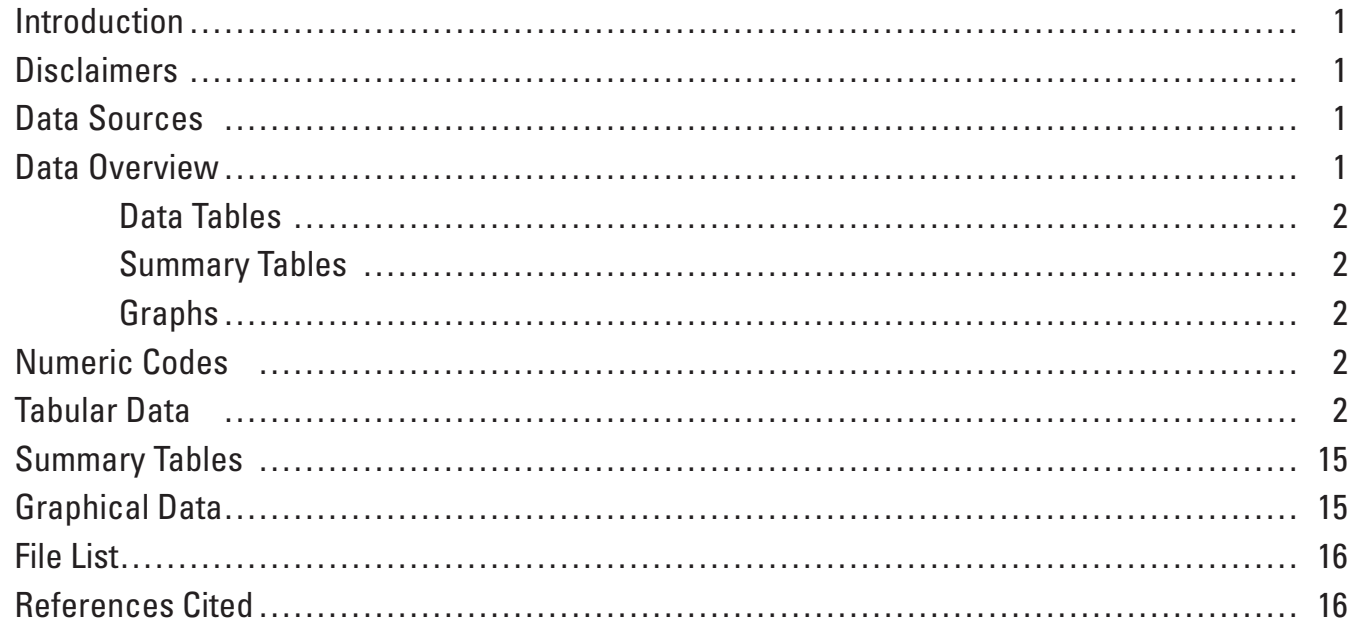

Note: Individual .pdf file names are listed on page 16 and are linked to the respective .pdf files 


\section{Tabular Data and Graphical Images in Support of the U.S. Geological Survey National Oil and Gas Assessment - The Wind River Basin Province}

By T.R. Klett and P.A. Le

\section{Introduction}

This chapter describes data used in support of the process being applied by the U.S. Geological Survey (USGS) National Oil and Gas Assessment (NOGA) project. Digital tabular data used in this report and archival data that permit the user to perform further analyses are available elsewhere on this CDROM. Computers and software may import the data without transcription from the Portable Document Format files (.pdf files) of the text by the reader. Graphical images are provided as .pdf files and tabular data are provided in a raw form as tab-delimited text files (.tab files) because of the number and variety of platforms and software available.

\section{Disclaimers}

This publication was prepared by an agency of the United States Government. Neither the United States Government nor any agency thereof, nor any of its employees, make any warranty, expressed or implied, or assume any legal liability or responsibility for the accuracy, completeness, or usefulness of any information, apparatus, product, or process disclosed in this report, or represent that its use would not infringe on privately owned rights. Reference therein to any specific commercial product, process, or service by trade name, trademark, manufacturer, or otherwise does not necessarily constitute or imply its endorsement, recommendation, or favoring by the United States Government or any agency thereof.

Although all data and software published on this CDROM have been used by the USGS, no warranty, expressed or implied, is made by the USGS as to the accuracy of the data and related materials. The act of distribution shall not constitute any such warranty, and no responsibility is assumed by the USGS in the use of these data or related materials.

\section{Data Sources}

Crude oil and natural gas production data (including all volumetric and descriptive data such as cumulative production, remaining reserves, known recoverable volumes, major producing reservoirs, and petroleum type) and historical data (including field-discovery dates, well-completion dates, exploration objectives, and well depths) for fields, reservoirs, and wells are derived from commercial databases leased and (or) purchased by the USGS, including (1) PI/Dwights Plus US Production Data (IHS Energy Group, 2005a), (2) PI/Dwights Plus US Well Data (IHS Energy Group, 2005b), (3) NRG Associates, Inc., The significant oil and gas fields of the United States (NRG Associates, 2005), as well as older versions of these databases. Data from these databases are subject to proprietary constraints, but derivative representations in the form of graphs and summary statistics are allowed to be published and were prepared for each assessment unit. Additional data are obtained, where available, from operators, other Federal and State agencies, or published geological reports to supplement commercial databases.

The PI/Dwights Plus US Production database provides production data for wells, leases, or production units. The PI/ Dwights Plus US Well database provides individual well data (including data for dry holes), including well identifications, locations, initial and final well status classifications, completion dates, and information on penetrated formations. The NRG Associates, Inc., Significant oil and gas fields of the United States database provides volumetric and production data for fields and reservoirs.

\section{Data Overview}

This report provides various data files supporting the NOGA project. The files contain data that are the source for the various graphs, data tables, and summary tables used in the assessment process. Tabular data are provided as tab- 
delimited text files (.tab files), usable in spreadsheet and database software. Graphical and summary data are provided as Portable Document Format files (.pdf files). File name conventions are as follows:

\section{Data Tables}

eco\#\#\#\#.tab

fed\#\#\#\#.tab

own\#\#\#\#.tab

sta\#\#\#\#.tab

vol\#\#\#\#.tab

inf\#\#\#\#.tab

ins\#\#\#\#.tab

kvol\#\#\#\#.tab

\section{Summary Tables}

c\#\#\#\#\#\#.pdf

d\#\#\#\#\#\#.pdf

u\#\#\#\#\#\#.pdf

\section{Graphs}

$$
\begin{aligned}
& \text { em\#\#\#\#\#\#.pdf } \\
& \text { fp\#\#\#\#\#\#.pdf } \\
& \text { g\#\#\#\#\#\#.pdf } \\
& \text { k\#\#\#\#\#\#.pdf }
\end{aligned}
$$

For identification purposes, numbers in the positions occupied by the four symbols "\#\#\#\#” represent the province code. Files with these numbers contain data for the entire province. Files having numbers in the positions occupied by the six symbols "\#\#\#\#\#\#," which represent the last six digits of the assessment-unit code, contain data only for that assessment unit.

\section{Numeric Codes}

A hierarchical numeric code identifies each region, province, total petroleum system, and assessment unit. The criteria for assigning codes are uniform throughout the NOGA project and throughout all resulting publications. The numeric codes used in this study are:

$\begin{array}{llr}\text { Unit } & \text { Name } & \text { Code } \\ \text { Region } & \text { North America } & \mathbf{5} \\ \text { Province } & \text { Wind River Basin } & 5035 \\ \text { Total Petroleum System } & \text { Phosphoria } & 503501 \\ & \text { Cretaceous-Lower } & \\ & \text { Tertiary Composite } & 503502\end{array}$

\author{
Unit \\ Total Petroleum \\ System \\ Assessment Units
}

$\begin{array}{lr}\text { Name } & \text { Code } \\ \text { Waltman Shale } & \\ \text { Tensleep-Park City } & 503503 \\ \text { Conventional Oil and Gas } 50350101 \\ \text { Cretaceous-Tertiary } & \\ \text { Conventional Oil and Gas } & 50350201 \\ \text { Frontier-Muddy } & \\ \text { Continuous Gas } & 50350261 \\ \text { Cody Sandstone } & \\ \text { Continuous Gas } & 50350262 \\ \text { Cody Fractured Shale } & \\ \text { Continuous Oil } & 50350263 \\ \text { Mesaverde-Meeteetse } & \\ \text { Sandstone Gas } & 50350264 \\ \text { Lance-Fort Union } & \\ \text { Sandstone Gas } & 50350265 \\ \text { Mesaverde Coalbed Gas } & 50350281 \\ \text { Meeteetse Coalbed Gas } & 50350282 \\ \text { Fort Union Coalbed Gas } & 50350283 \\ \text { Upper Fort Union } & \\ \text { Sandstones Conventional } & \\ \text { Oil and Gas } & 50350301 \\ \text { Waltman Fractured Shale } & \\ \text { Continuous Oil } & 50350361\end{array}$

The assessment-unit portion of the code (last two digits) defines the type of assessment unit. Numbers from 01 to 59 represent conventional assessment units; 61 to 79 represent continuous oil or gas assessment units; and 81 to 99 represent coalbed-gas assessment units. No total petroleum system or assessment-unit codes end with 0, for example 503500, 50350160 or 50350180 .

To maintain the conventional labeling of files (8-character name and 3-character extension), some file names that contain assessment-unit numbers do not include the first two digits. A summary table that contains input data for the Tensleep-Park City Oil and Gas Assessment Unit is labeled "c350101.pdf" for example.

\section{Tabular Data}

The eco\#\#\#\#.tab, fed\#\#\#\#.tab, own\#\#\#\#.tab, and sta\#\#\#\#.tab files contain volume-percent data of undiscovered petroleum allocated to ecosystem regions, Federal lands, general land-ownership parcels, and States. Cells are left blank if data are unavailable.

The eco\#\#\#\#.tab table contains 59 columns. The sum of the percentages should equal those for the total area (excluding offshore) in the own\#\#\#\#.tab file. Data columns for these files are:

(1) Code-assessment-unit code number.

(2) Name-assessment-unit name.

(3) Area $\mathrm{km}^{2}$ - area of the assessment unit in square kilometers. 
(4) Eco 1-name of first ecosystem that occupies all or part of the assessment-unit area.

(5) E1 Area \% - percentage of assessment-unit area that is occupied by ecosystem 1 .

(6) E1 Oil \% - estimated percentage of undiscovered oil volume allocated to ecosystem 1.

(7) E1 Gas \% - estimated percentage of undiscovered gas volume allocated to ecosystem 1 .

(8) Eco 2-name of second ecosystem that occupies part of the assessment-unit area.

(9) E2 Area \% - percentage of assessment-unit area that is occupied by ecosystem 2 .

(10) E2 Oil \% - estimated percentage of undiscovered oil volume allocated to ecosystem 2 .

(11) E2 Gas \% - estimated percentage of undiscovered gas volume allocated to ecosystem 2 .

(12) Eco 3-name of third ecosystem that occupies part of the assessment-unit area.

(13) E3 Area \% - percentage of assessment-unit area that is occupied by ecosystem 3 .

(14) E3 Oil \% - estimated percentage of undiscovered oil volume allocated to ecosystem 3 .

(15) E3 Gas \% - estimated percentage of undiscovered gas volume allocated to ecosystem 3 .

(16) Eco 4 - name of fourth ecosystem that occupies part of the assessment-unit area.

(17) E4 Area \% - percentage of assessment-unit area that is occupied by ecosystem 4 .

(18) E4 Oil \% - estimated percentage of undiscovered oil volume allocated to ecosystem 4.

(19) E4 Gas \%-estimated percentage of undiscovered gas volume allocated to ecosystem 4 .

(20) Eco 5-name of fifth ecosystem that occupies part of the assessment-unit area.

(21) E5 Area \% - percentage of assessment-unit area that is occupied by ecosystem 5 .

(22) E5 Oil \% - estimated percentage of undiscovered oil volume allocated to ecosystem 5 .

(23) E5 Gas \% - estimated percentage of undiscovered gas volume allocated to ecosystem 5 .

(24) Eco 6-name of sixth ecosystem that occupies part of the assessment-unit area.

(25) E6 Area \%-percentage of assessment-unit area that is occupied by ecosystem 6 .

(26) E6 Oil \% - estimated percentage of undiscovered oil volume allocated to ecosystem 6 .

(27) E6 Gas \%- estimated percentage of undiscovered gas volume allocated to ecosystem 6 .

(28) Eco 7-name of seventh ecosystem that occupies part of the assessment-unit area.

(29) E7 Area \%-- percentage of assessment-unit area that is occupied by ecosystem 7 .

(30) E7 Oil \% - estimated percentage of undiscovered oil volume allocated to ecosystem 7 .

(31) E7 Gas \% - estimated percentage of undiscovered gas volume allocated to ecosystem 7.
(32) Eco 8-name of eighth ecosystem that occupies part of the assessment-unit area.

(33) E8 Area \% - percentage of assessment-unit area that is occupied by ecosystem 8 .

(34) E8 Oil \%-estimated percentage of undiscovered oil volume allocated to ecosystem 8 .

(35) E8 Gas \% - estimated percentage of undiscovered gas volume allocated to ecosystem 8 .

(36) Eco 9-name of ninth ecosystem that occupies part of the assessment-unit area.

(37) E9 Area \% - percentage of assessment-unit area that is occupied by ecosystem 9 .

(38) E9 Oil \% - estimated percentage of undiscovered oil volume allocated to ecosystem 9.

(39) E9 Gas \% - estimated percentage of undiscovered gas volume allocated to ecosystem 9 .

(40) Eco 10 - name of tenth ecosystem that occupies part of the assessment-unit area.

(41) E10 Area \% - percentage of assessment-unit area that is occupied by ecosystem 10 .

(42) E10 Oil \% - estimated percentage of undiscovered oil volume allocated to ecosystem 10 .

(43) E10 Gas \% - estimated percentage of undiscovered gas volume allocated to ecosystem 10 .

(44) Eco 11-name of eleventh ecosystem that occupies part of the assessment-unit area.

(45) E11 Area \% - percentage of assessment-unit area that is occupied by ecosystem 11 .

(46) E11 Oil \% - estimated percentage of undiscovered oil volume allocated to ecosystem 11.

(47) E11 Gas \% - estimated percentage of undiscovered gas volume allocated to ecosystem 11.

(48) Eco 12 - name of twelfth ecosystem that occupies part of the assessment-unit area.

(49) E12 Area \% - percentage of assessment-unit area that is occupied by ecosystem 12 .

(50) E12 Oil \% - estimated percentage of undiscovered oil volume allocated to ecosystem 12 .

(51) E12 Gas \%-estimated percentage of undiscovered gas volume allocated to ecosystem 12 .

(52) Eco 13-name of thirteenth ecosystem that occupies part of the assessment-unit area.

(53) E13 Area \% - percentage of assessment-unit area that is occupied by ecosystem 13 .

(54) E13 Oil \% - estimated percentage of undiscovered oil volume allocated to ecosystem 13 .

(55) E13 Gas \% - estimated percentage of undiscovered gas volume allocated to ecosystem 13 .

(56) Eco 14 - name of fourteenth ecosystem that occupies part of the assessment-unit area.

(57) E14 Area \% - percentage of assessment-unit area that is occupied by ecosystem 14 .

(58) E14 Oil \% - estimated percentage of undiscovered oil volume allocated to ecosystem 14 .

(59) E14 Gas \% - estimated percentage of undiscovered gas volume allocated to ecosystem 14. 
The fed\#\#\#\#.tab table contains 83 columns. The sum of the percentages should equal those for Federal lands in the own\#\#\#\#.tab file. Data columns for these files are:

(1) Code - assessment-unit code number.

(2) Name-assessment-unit name.

(3) Area $\mathrm{km}^{2}$ - area of the assessment unit in square kilometers.

(4) BLM - "Bureau of Land Management," name of Federal land that occupies all or part of the assessment-unit area.

(5) BLM Area \%-percentage of assessment-unit area that is occupied by Bureau of Land Management lands.

(6) BLM Oil \% — - estimated percentage of undiscovered oil volume allocated to Bureau of Land Management lands.

(7) BLM Gas \% - estimated percentage of undiscovered gas volume allocated to Bureau of Land Management lands.

(8) BLMW - "BLM Wilderness Areas," name of

Federal land that occupies all or part of the assessmentunit area.

(9) BLMWArea \% - percentage of assessment-unit area that is occupied by Bureau of Land Management Wilderness Areas.

(10) BLMW Oil \% — estimated percentage of undiscovered oil volume allocated to Bureau of Land Management Wilderness Areas.

(11) BLMW Gas \% - estimated percentage of undiscovered gas volume allocated to Bureau of Land Management Wilderness Areas.

(12) BLMR - “BLM Roadless Areas," name of Federal land that occupies all or part of the assessmentunit area.

(13) BLMRArea \%-percentage of assessment-unit area that is occupied by Bureau of Land Management Roadless Areas.

(14) BLMR Oil \% — estimated percentage of undiscovered oil volume allocated to Bureau of Land Management Roadless Areas.

(15) BLMR Gas \%-estimated percentage of undiscovered gas volume allocated to Bureau of Land Management Roadless Areas.

(16) NPS_ _National Park Service," name of Federal land that occupies all or part of the assessment-unit area.

(17) NPS Area \% - percentage of assessment-unit area that is occupied by National Park Service lands.

(18) NPS Oil \% - estimated percentage of undiscovered oil volume allocated to National Park Service lands.

(19) NPS Gas \% - estimated percentage of undiscovered gas volume allocated to National Park Service lands.

(20) NPSW_- "NPS Wilderness Areas," name of Federal land that occupies all or part of the assessment-unit area.

(21) NPSWArea \% - percentage of assessment-unit area that is occupied by National Park Service Wilderness Areas.

(22) NPSW Oil \% - estimated percentage of undiscovered oil volume allocated to National Park Service Wilderness Areas.

(23) NPSW Gas \% - estimated percentage of undiscovered gas volume allocated to National Park Service Wilderness Areas.
(24) NPSP - "NPS Withdrawals," name of Federal land that occupies all or part of the assessment-unit area.

(25) NPSPArea $\%$ - percentage of assessment-unit area that is occupied by National Park Service Withdrawals.

(26) NPSP Oil \% - estimated percentage of undiscovered oil volume allocated to National Park Service Withdrawals.

(27) NPSP Gas \% - estimated percentage of undiscovered gas volume allocated to National Park Service Withdrawals.

(28) FS - "Forest Service," name of Federal land that occupies all or part of the assessment-unit area.

(29) FS Area \% - percentage of assessment-unit area that is occupied by USDA (U.S. Department of Agriculture), Forest Service lands.

(30) FS Oil \% — estimated percentage of undiscovered oil volume allocated to USDA Forest Service lands.

(31) FS Gas \% - estimated percentage of undiscovered gas volume allocated to USDA Forest Service lands.

(32) FSW-“FS Wilderness Areas," name of Federal land that occupies all or part of the assessment-unit area.

(33) FSW Area \% - percentage of assessment-unit area that is occupied by USDA Forest Service Wilderness Areas.

(34) FSW Oil \% - estimated percentage of undiscovered oil volume allocated to USDA Forest Service Wilderness Areas.

(35) FSW Gas \% - estimated percentage of undiscovered gas volume allocated to USDA Forest Service Wilderness Areas.

(36) FSR - “FS Roadless Areas," name of Federal land that occupies all or part of the assessment-unit area.

(37) FSR Area \% - percentage of assessment-unit area that is occupied by USDA Forest Service Roadless Areas.

(38) FSR Oil \% - estimated percentage of undiscovered oil volume allocated to USDA Forest Service Roadless Areas.

(39) FSR Gas \% - estimated percentage of undiscovered gas volume allocated to USDA Forest Service Roadless Areas.

(40) FSP — "FS Protected Withdrawals," name of Federal land that occupies all or part of the assessment-unit area.

(41) FSP Area \% - percentage of assessment-unit area that is occupied by USDA Forest Service Protected Withdrawals.

(42) FSP Oil \% - estimated percentage of undiscovered oil volume allocated to USDA Forest Service Protected Withdrawals.

(43) FSP Gas \% - estimated percentage of undiscovered gas volume allocated to USDA Forest Service Protected Withdrawals.

(44) FWS - “U.S. Fish and Wildlife Service (USFWS)," name of Federal land that occupies all or part of the assessment-unit area.

(45) FWS Area \% - percentage of assessment-unit area that is occupied by U.S. Fish and Wildlife Service lands.

(46) FWS Oil \% - estimated percentage of undiscovered oil volume allocated to U.S. Fish and Wildlife Service lands.

(47) FWS Gas \% - estimated percentage of undiscovered gas volume allocated to U.S. Fish and Wildlife Service lands. 
(48) FWSW- - "USFWS Wilderness Areas (USFWSW)," name of Federal land that occupies all or part of the assessment-unit area.

(49) FWSWArea \% - percentage of assessment-unit area that is occupied by U.S. Fish and Wildlife Service Wilderness Areas.

(50) FWSW Oil \%- estimated percentage of undiscovered oil volume allocated to U.S. Fish and Wildlife Service Wilderness Areas.

(51) FWSW Gas \% - estimated percentage of undiscovered gas volume allocated to U.S. Fish and Wildlife Service Wilderness Areas.

(52) FWSP-“USFWS Protected Withdrawals (USFWSP)," name of Federal land that occupies all or part of the assessment-unit area.

(53) FWSPArea \% - percentage of assessment-unit area that is occupied by U.S. Fish and Wildlife Service Protected Withdrawals.

(54) FWSP Oil \% - estimated percentage of undiscovered oil volume allocated to U.S. Fish and Wildlife Service Protected Withdrawals.

(55) FWSP Gas \% - estimated percentage of undiscovered gas volume allocated to U.S. Fish and Wildlife Service Protected Withdrawals.

(56) WS- "Wilderness Study Areas," name of Federal land that occupies all or part of the assessment-unit area.

(57) WS Area \%-percentage of assessment-unit area that is occupied by Wilderness Study Areas.

(58) WS Oil \%-estimated percentage of undiscovered oil volume allocated to Wilderness Study Areas.

(59) WS Gas \% - estimated percentage of undiscovered gas volume allocated to Wilderness Study Areas.

(60) DOE— - "Department of Energy," name of Federal land that occupies all or part of the assessment-unit area.

(61) DOE Area \% - percentage of assessment-unit area that is occupied by Department of Energy lands.

(62) DOE Oil \% - estimated percentage of undiscovered oil volume allocated to Department of Energy lands.

(63) DOE Gas \% - estimated percentage of undiscovered gas volume allocated to Department of Energy lands.

(64) DOD - "Department of Defense," name of Federal land that occupies all or part of the assessment-unit area.

(65) DOD Area \% - percentage of assessment-unit area that is occupied by Department of Defense lands.

(66) DOD Oil \% - estimated percentage of undiscovered oil volume allocated to Department of Defense lands.

(67) DOD Gas \% - estimated percentage of undiscovered gas volume allocated to Department of Defense lands.

(68) BOR-"Bureau of Reclamation," name of Federal land that occupies all or part of the assessment-unit area.

(69) BOR Area \% - percentage of assessment-unit area that is occupied by Bureau of Reclamation lands.

(70) BOR Oil \% - estimated percentage of undiscovered oil volume allocated to Bureau of Reclamation lands.

(71) BOR Gas \%-estimated percentage of undiscovered gas volume allocated to Bureau of Reclamation lands.
(72) TVA- “Tennessee Valley Authority," name of Federal land that occupies all or part of the assessment-unit area.

(73) TVA Area \% - percentage of assessment-unit area that is occupied by Tennessee Valley Authority lands.

(74) TVA Oil \%-estimated percentage of undiscovered oil volume allocated to Tennessee Valley Authority lands.

(75) TVA Gas \% - estimated percentage of undiscovered gas volume allocated to Tennessee Valley Authority lands.

(76) Oth - "Other Federal," other unspecified Federal lands that occupy all part of the assessment-unit area.

(77) Oth Area \% - percentage of assessment-unit area that is occupied by other unspecified Federal lands.

(78) Oth Oil \% - estimated percentage of undiscovered oil volume allocated to other unspecified Federal lands.

(79) Oth Gas \%- estimated percentage of undiscovered gas volume allocated to other unspecified Federal lands.

(80) F20 - name of additional specified Federal lands that occupy all or part of the assessment-unit area.

(81) F20 Area \% - percentage of assessment-unit area that is occupied by additional specified Federal lands.

(82) F20 Oil \%- estimated percentage of undiscovered oil volume allocated to additional specified Federal lands.

(83) F20 Gas \%-estimated percentage of undiscovered gas volume allocated to additional specified Federal lands.

The own\#\#\#\#.tab table contains 59 columns. The sum of the percentages should equal 100. Data columns for these files are:

(1) Code-assessment-unit code number.

(2) Name - assessment-unit name.

(3) Area $\mathrm{km}^{2}$ - area of the assessment unit in square kilometers.

(4) Fed- - Federal Lands," all Federal lands that occupy all or part of the assessment-unit area.

(5) Fed Area \% - percentage of assessment-unit area that is occupied by Federal lands.

(6) Fed Oil \% - estimated percentage of undiscovered oil volume allocated to Federal lands.

(7) Fed Gas \%- estimated percentage of undiscovered gas volume allocated to Federal lands.

(8) Pri- "Private Lands," all private lands that occupy all or part of the assessment-unit area.

(9) Pri Area \%-percentage of assessment-unit area that is occupied by private lands.

(10) Pri Oil \% - estimated percentage of undiscovered oil volume allocated to private lands.

(11) Pri Gas \%-estimated percentage of undiscovered gas volume allocated to private lands.

(12) Tri- "Tribal Lands," all tribal lands that occupy all or part of the assessment-unit area.

(13) Tri Area \% - percentage of assessment-unit area that is occupied by tribal lands.

(14) Tri Oil \%-estimated percentage of undiscovered oil volume allocated to tribal lands.

(15) Tri Gas \%-estimated percentage of undiscovered gas volume allocated to tribal lands. 
(16) Oth—name of other unspecified lands or offshore areas that occupy all or part of the assessment-unit area.

(17) Oth Area \% - percentage of assessment-unit area that is occupied by other unspecified lands or offshore areas.

(18) Oth Oil \% - estimated percentage of undiscovered oil volume allocated to other unspecified lands or offshore areas.

(19) Oth Gas \%-estimated percentage of undiscovered gas volume allocated to other unspecified lands or offshore areas.

(20) S1-name of first State (State1), for which State-owned lands or waters occupy all or part of the assessment-unit area.

(21) S1 Area \%-percentage of assessment-unit area that is occupied by State 1-owned lands or waters.

(22) S1 Oil \% - estimated percentage of undiscovered oil volume allocated to State 1-owned lands or waters.

(23) S1 Gas \% - estimated percentage of undiscovered gas volume allocated to State 1-owned lands or waters.

(24) S2 - name of second State (State 2), for which State-owned lands or waters occupy all or part of the assessment-unit area.

(25) S2 Area \%-percentage of assessment-unit area that is occupied by State 2-owned lands or waters.

(26) S2 Oil \%-estimated percentage of undiscovered oil volume allocated to State 2-owned lands or waters.

(27) S2 Gas \%-estimated percentage of undiscovered gas volume allocated to State 2-owned lands or waters.

(28) S3 - name of third State (State 3), for which State-owned lands or waters occupy all or part of the assessment-unit area.

(29) S3 Area \%-percentage of assessment-unit area that is occupied by State 3 -owned lands or waters.

(30) S3 Oil \%-estimated percentage of undiscovered oil volume allocated to State 3-owned lands or waters.

(31) S3 Gas \%-estimated percentage of undiscovered gas volume allocated to State 3-owned lands or waters.

(32) S4 - name of fourth State (State 4), for which State-owned lands or waters occupy all or part of the assessment-unit area.

(33) S4 Area \%-percentage of assessment-unit area that is occupied by State 4-owned lands or waters.

(34) S4 Oil \%-estimated percentage of undiscovered oil volume allocated to State 4-owned lands or waters.

(35) S4 Gas \%-estimated percentage of undiscovered gas volume allocated to State 4-owned lands or waters.

(36) S5-name of fifth State (State 5), for which State-owned lands or waters occupy all or part of the assessment-unit area.

(37) S5 Area \%-percentage of assessment-unit area that is occupied by State 5-owned lands or waters.

(38) S5 Oil \%-estimated percentage of undiscovered oil volume allocated to State 5-owned lands or waters.

(39) S5 Gas \% - estimated percentage of undiscovered gas volume allocated to State 5-owned lands or waters.

(40) S6-name of sixth State (State 6), for which State-owned lands or waters occupy all or part of the assessment-unit area.

(41) S6 Area \%-percentage of assessment-unit area that is occupied by State 6-owned lands or waters.

(42) S6 Oil \%-estimated percentage of undiscovered oil volume allocated to State 6-owned lands or waters.

(43) S6 Gas \%-estimated percentage of undiscovered gas volume allocated to State 6-owned lands or waters.

(44) S7-name of seventh State (State 7), for which State-owned lands or waters occupy all or part of the assessment-unit area.

(45) S7 Area \%-percentage of assessment-unit area that is occupied by State 7-owned lands or waters.

(46) S7 Oil \%-estimated percentage of undiscovered oil volume allocated to State 7-owned lands or waters.

(47) S7 Gas \% - estimated percentage of undiscovered gas volume allocated to State 7-owned lands or waters.

(48) S8 - name of eighth State (State 8), for which State-owned lands or waters occupy all or part of the assessment-unit area.

(49) S8 Area \%-percentage of assessment-unit area that is occupied by State 8-owned lands or waters.

(50) S8 Oil \%-estimated percentage of undiscovered oil volume allocated to State 8-owned lands or waters.

(51) S8 Gas \%-estimated percentage of undiscovered gas volume allocated to State 8-owned lands or waters.

(52) S9-name of ninth State (State 9), for which State-owned lands or waters occupy all or part of the assessment-unit area.

(53) S9 Area \%-percentage of assessment-unit area that is occupied by State 9-owned lands or waters.

(54) S9 Oil \%-estimated percentage of undiscovered oil volume allocated to State 9-owned lands or waters.

(55) S9 Gas \%-estimated percentage of undiscovered gas volume allocated to State 9-owned lands or waters.

(56) S10 - name of tenth State (State 10), for which State-owned lands or waters occupy all or part of the assessment-unit area.

(57) S10 Area \%-percentage of assessment-unit area that is occupied by State 10-owned lands or waters.

(58) S10 Oil \%-estimated percentage of undiscovered oil volume allocated to State 10-owned lands or waters.

(59) S10 Gas \%-estimated percentage of undiscovered gas volume allocated to State 10-owned lands or waters.

The sta\#\#\#.tab table contains 59 columns. The sum of the percentages should equal 100. Data columns for these files are:

(1) Code-assessment-unit code number.

(2) Name-assessment-unit name.

(3) Area $\mathrm{km}^{2}$-area of the assessment unit in square kilometers.

(4) S1-name of first State (State 1), (onshore and offshore) that occupies all or part of the assessment-unit area.

(5) S1 Area \%-percentage of assessment-unit area that is occupied by State 1. 
(6) S1 Oil \%-estimated percentage of undiscovered oil volume allocated to State 1.

(7) S1 Gas \%-estimated percentage of undiscovered gas volume allocated to State 1.

(8) S2-name of second State (State 2), (onshore and offshore) that occupies all or part of the assessment-unit area.

(9) S2 Area \% - percentage of assessment-unit area that is occupied by State 2 .

(10) S2 Oil \%-estimated percentage of undiscovered oil volume allocated to State 2.

(11) S2 Gas \%-estimated percentage of undiscovered gas volume allocated to State 2.

(12) S3 - name of third State (State 3), (onshore and offshore) that occupies all or part of the assessment-unit area.

(13) S3 Area \%-percentage of assessment-unit area that is occupied by State 3.

(14) S3 Oil \%-estimated percentage of undiscovered oil volume allocated to State 3.

(15) S3 Gas \%-estimated percentage of undiscovered gas volume allocated to State 3 .

(16) S4-name of fourth State (State 4), (onshore and offshore) that occupies all or part of the assessmentunit area.

(17) S4 Area \%-percentage of assessment-unit area that is occupied by State 4 .

(18) S4 Oil \%-estimated percentage of undiscovered oil volume allocated to State 4.

(19) S4 Gas \%-estimated percentage of undiscovered gas volume allocated to State 4.

(20) S5-name of fifth State (State 5), (onshore and offshore) that occupies all or part of the assessment-unit area.

(21) S5 Area \%-percentage of assessment-unit area that is occupied by State 5 .

(22) S5 Oil \%-estimated percentage of undiscovered oil volume allocated to State 5 .

(23) S5 Gas \%-estimated percentage of undiscovered gas volume allocated to State 5 .

(24) S6 - name of sixth State (State 6), (onshore and offshore) that occupies all or part of the assessment-unit area.

(25) S6 Area \%-percentage of assessment-unit area that is occupied by State 6.

(26) S6 Oil \%-estimated percentage of undiscovered oil volume allocated to State 6.

(27) S6 Gas \%-estimated percentage of undiscovered gas volume allocated to State 6.

(28) S7-name of seventh State (State 7), (onshore and offshore) that occupies all or part of the assessment-unit area.

(29) S7 Area \%-percentage of assessment-unit area that is occupied by State 7 .

(30) S7 Oil \%-estimated percentage of undiscovered oil volume allocated to State 7.

(31) S7 Gas \% —estimated percentage of undiscovered gas volume allocated to State 7.
(32) S8 - name of eighth State (State 8), (onshore and offshore) that occupies all or part of the assessmentunit area.

(33) S8 Gas \%-percentage of assessment-unit area that is occupied by State 8 .

(34) S8 Oil \%-estimated percentage of undiscovered oil volume allocated to State 8 .

(35) S8 Gas \%-estimated percentage of undiscovered gas volume allocated to State 8 .

(36) S9-name of ninth State (State 9), (onshore and offshore) that occupies all or part of the assessment-unit area.

(37) S9 Area \%-percentage of assessment-unit area that is occupied by State 9.

(38) S9 Oil \%—estimated percentage of undiscovered oil volume allocated to State 9.

(39) S9 Gas \%-estimated percentage of undiscovered gas volume allocated to State 9.

(40) S10 — name of tenth State (State 10), (onshore and offshore) that occupies all or part of the assessmentunit area.

(41) S10 Area \%-percentage of assessment-unit area that is occupied by State 10 .

(42) S10 Oil \% - estimated percentage of undiscovered oil volume allocated to State 10.

(43) S10 Gas \%-estimated percentage of undiscovered gas volume allocated to State 10.

(44) S11-name of eleventh State (State 11), (onshore and offshore) that occupies all or part of the assessment-unit area.

(45) S11 Area \%-percentage of assessment-unit area that is occupied by State 11.

(46) S11 Oil \%-estimated percentage of undiscovered oil volume allocated to State 11.

(47) S11 Gas \%—estimated percentage of undiscovered gas volume allocated to State 11.

(48) S12-name of twelfth State (State 12), (onshore and offshore) that occupies all or part of the assessment-unit area.

(49) S12 Area \% - percentage of assessment-unit area that is occupied by State 12 .

(50) S12 Oil \%-estimated percentage of undiscovered oil volume allocated to State 12.

(51) S12 Gas \%-estimated percentage of undiscovered gas volume allocated to State 12 .

(52) S13 - name of thirteenth State (State 13), (onshore and offshore) that occupies all or part of the assessment-unit area.

(53) S13 Area \%-percentage of assessment-unit area that is occupied by State 13 .

(54) S13 Oil \%-estimated percentage of undiscovered oil volume allocated to State 13 .

(55) S13 Gas \%-estimated percentage of undiscovered gas volume allocated to State 13 .

(56) S14-name of fourteenth State (State 14), (onshore and offshore) that occupies all or part of the assessmentunit area. 
(57) S14 Area \%-percentage of assessment-unit area that is occupied by State 14 .

(58) S14 Oil \%-estimated percentage of undiscovered oil volume allocated to State 14.

(59) S14 Gas \%-estimated percentage of undiscovered gas volume allocated to State 14

The vol\#\#\#\#.tab table contains estimates of undiscovered petroleum resources along with parameters that express uncertainty in these estimates. The table contains 40 columns. Blank cells represent no data. Data columns for these files are:

(1) Code-assessment-unit code number.

(2) Name-assessment-unit name.

(3) Type-type of assessment unit, conventional, continuous oil, continuous gas, or coalbed gas.

(4) Status-remarks indicating that assessment unit was not quantitatively assessed; otherwise blank.

(12) Eco 3-name of third ecosystem that occupies part of the assessment-unit area.

(5) Prob \% - geologic probability of the assessment unit.

(6) OILF95 MMB - the estimated value of undiscovered oil (oil in oil accumulations) such that there is a 95percent probability that this amount or more exists in the assessment unit. The volume is given in millions of barrels of oil (MMBO).

(7) OILF50 MMB - the estimated value of undiscovered oil (oil in oil accumulations) such that there is a 50-percent probability that this amount or more exists in the assessment unit. This is the median value. The volume is given in millions of barrels of oil (MMBO).

(8) OILF5 MMB - the estimated value of undiscovered oil (oil in oil accumulations) such that there is a 5-percent probability that this amount or more exists in the assessment unit. The volume is given in millions of barrels of oil (MMBO).

(9) OILMN MMB - the estimated mean (average) value of undiscovered oil (oil in oil accumulations). The volume is given in millions of barrels of oil (MMBO).

(10) OILSD MMB - the estimated standard deviation value of undiscovered oil (oil in oil accumulations). The volume is given in millions of barrels of oil (MMBO).

(11) AGF95 BCF - the estimated value of undiscovered associated/dissolved gas (gas in oil accumulations) such that there is a 95 -percent probability that this amount or more exists in the assessment unit. The volume is given in billions of cubic feet of gas (BCFG).

(12) AGF50 BCF - the estimated value of undiscovered associated/dissolved gas (gas in oil accumulations) such that there is a 50-percent probability that this amount or more exists in the assessment unit. This is the median value. The volume is given in billions of cubic feet of gas (BCFG).

(13) AGF5 BCF - the estimated value of undiscovered associated/dissolved gas (gas in oil accumulations) such that there is a 5-percent probability that this amount or more exists in the assessment unit. The volume is given in billions of cubic feet of gas (BCFG).

(14) AGMN BCF - the estimated mean (average) value of undiscovered associated/dissolved gas (gas in oil accumulations). The volume is given in billions of cubic feet of gas (BCFG).

(15) AGSD BCF - the estimated standard deviation value of undiscovered associated/dissolved gas (gas in oil accumulations). The volume is given in billions of cubic feet of gas (BCFG).

(16) NGLF95 MMB - the estimated value of undiscovered natural gas liquids (NGL in oil accumulations) such that there is a 95-percent probability that this amount or more exists in the assessment unit. The volume is given in millions of barrels of NGL (MMBNGL).

(17) NGLF50 MMB - the estimated value of undiscovered natural gas liquids (NGL in oil accumulations) such that there is a 50-percent probability that this amount or more exists in the assessment unit. This is the median value. The volume is given in millions of barrels of NGL (MMBNGL).

(18) NGLF5 MMB - the estimated value of undiscovered natural gas liquids (NGL in oil accumulations) such that there is a 5-percent probability that this amount or more exists in the assessment unit. The volume is given in millions of barrels of NGL (MMBNGL).

(19) NGLMN MMB - the estimated mean (average) value of undiscovered natural gas liquids (NGL in oil accumulations). The volume is given in millions of barrels of NGL (MMBNGL).

(20) NGLSD MMB - the estimated standard deviation value of undiscovered natural gas liquids (NGL in oil accumulations). The volume is given in millions of barrels of NGL (MMBNGL).

(21) NGF95 BCF - the estimated value of undiscovered nonassociated gas (gas in gas accumulations) such that there is a 95-percent probability that this amount or more exists in the assessment unit. The volume is given in billions of cubic feet of gas (BCFG).

(22) NGF50 BCF - the estimated value of undiscovered nonassociated gas (gas in gas accumulations) such that there is a 50-percent probability that this amount or more exists in the assessment unit. This is the median value. The volume is given in billions of cubic feet of gas (BCFG).

(23) NGF5 BCF - the estimated value of undiscovered nonassociated gas (gas in gas accumulations) such that there is a 5-percent probability that this amount or more exists in the assessment unit. The volume is given in billions of cubic feet of gas (BCFG).

(24) NGMN BCF - the estimated mean (average) value of undiscovered nonassociated gas (gas in gas accumulations). The volume is given in billions of cubic feet of gas (BCFG).

(25) NGSD BCF - the estimated standard deviation value of undiscovered nonassociated gas (gas in gas accumulations). The volume is given in billions of cubic feet of gas (BCFG). 
(26) LIQF95 MMB - the estimated value of undiscovered liquids (oil and NGL in gas accumulations) such that there is a 95-percent probability that this amount or more exists in the assessment unit. The volume is given in millions of barrels of liquids (MMBL).

(27) LIQF50 MMB - the estimated value of undiscovered liquids (oil and NGL in gas accumulations) such that there is a 50-percent probability that this amount or more exists in the assessment unit. This is the median value. The volume is given in millions of barrels of liquids (MMBL).

(28) LIQF5 MMB - the estimated value of undiscovered liquids (oil and NGL in gas accumulations) such that there is a 5-percent probability that this amount or more exists in the assessment unit. The volume is given in millions of barrels of liquids (MMBL).

(29) LIQMN MMB - the estimated mean (average) value of undiscovered liquids (oil and NGL in gas accumulations). The volume is given in millions of barrels of liquids (MMBL).

(30) LIQSD MMB - the estimated standard deviation value of undiscovered liquids (oil and NGL in gas accumulations). The volume is given in millions of barrels of liquids (MMBL).

(31) LOF95 MMB - the estimated size of the largest undiscovered conventional oil accumulation such that there is a 95-percent probability of that accumulation being this amount or larger. The volume is given in millions of barrels of oil (MMBO).

(32) LOF50 MMB - the estimated size of the largest undiscovered conventional oil accumulation such that there is a 50-percent probability of that accumulation being this amount or larger. This is the median value. The volume is given in millions of barrels of oil (MMBO).

(33) LOF5 MMB - the estimated size of the largest undiscovered conventional oil accumulation such that there is a 5-percent probability of that accumulation being this amount or larger. The volume is given in millions of barrels of oil (MMBO).

(34) LOMN MMB - the estimated mean (average) value of the largest undiscovered conventional oil accumulation. The volume is given in millions of barrels of oil (MMBO).

(35) LOSD MMB - the estimated standard deviation value of the largest undiscovered conventional oil accumulation. The volume is given in millions of barrels of oil (MMBO).

(36) LGF95 BCF - the estimated size of the largest undiscovered conventional gas accumulation such that there is a 95-percent probability of that accumulation being this amount or larger. The volume is given in billions of cubic feet of gas (BCFG).

(37) LGF50 BCF - the estimated size of the largest undiscovered conventional gas accumulation such that there is a 50-percent probability of that accumulation being this amount or larger. This is the median value. The volume is given in billions of cubic feet of gas (BCFG).

(38) LGF5 BCF - the estimated size of the largest undiscovered conventional gas accumulation such that there is a 5-percent probability of that accumulation being this amount or larger. The volume is given in billions of cubic feet of gas (BCFG).

(39) LGMN BCF - the estimated mean (average) value of the largest undiscovered conventional gas accumulation. The volume is given in billions of cubic feet of gas (BCFG).

(40) LGSD BCF - the estimated standard deviation value of the largest undiscovered conventional gas accumulation. The volume is given in billions of cubic feet of gas (BCFG).

The inf\#\#\#\#.tab table contains input data from the FORSPAN Assessment Model for Continuous Accumulations-Basic Input Data Form used in this assessment and provided in the u\#\#\#\#\#.pdf files. Cells are left blank if data are unavailable. This table contains 99 columns. Data columns are:

(1) Date-date of assessment.

(2) Geol—assessing geologist's name.

(3) Regno-region code number.

(4) Reg-region name.

(5) Provno-province code number.

(6) Prov-province name.

(8) TPSno - total petroleum system code number.

(9) TPS - total petroleum system name.

(10) AUno-assessment-unit code number.

(11) AU—assessment-unit name.

(12) Data1 - data sources used to aid in completing the datainput form.

(13) Data2 - continuation of data sources used to aid in completing the data-input form.

(14) Comm — assessment unit type, the primary commodity type in the assessment unit, based on the gas-to-oil ratio of the petroleum endowment, which includes both the discovered and undiscovered petroleum. An assessment unit is characterized as being oil prone if the gas-tooil ratio is less than 20,000 cubic feet of gas per barrel of oil; otherwise, it is gas prone.

(15) RminMMBBCF - minimum total recovery per cell considered for assessment, in million barrels of oil (MMBO) for oil assessment units or billion cubic feet of gas (BCFG) for gas assessment units.

(16) Numtest1 - number of tested cells in the assessment unit.

(17) Numtest2 - number of tested cells in the assessment unit that have total recoveries equal to or larger than the specified minimum total recovery per cell.

(18) AUM-assessment-unit maturity, the exploration maturity of the assessment unit. Assessment-unit maturity is classified as "established" if more than 24 cells exceed the minimum total recovery, "frontier" if 1 to 24 cells exceed the minimum total recovery, or "hypothetical" if no cells exceed the minimum total recovery.

(19) Med1MMBBCF - median total recovery per cell of the set of tested cells equal to or greater than the minimum total recovery that constitute the first one-third of the total number of cells ranked according to date of discovery 
within the assessment unit, in million barrels of oil (MMBO) for oil assessment units or billion cubic feet of gas (BCFG) for gas assessment units.

(20) Med2MMBBCF - median total recovery per cell of the set of tested cells equal to or greater than the minimum total recovery that constitute the second one-third of the total number of cells ranked according to date of discovery within the assessment unit, in million barrels of oil (MMBO) for oil assessment units or billion cubic feet of gas (BCFG) for gas assessment units.

(21) Med3MMBBCF - median total recovery per cell of the set of tested cells equal to or greater than the minimum total recovery that constitute the third one-third of the total number of cells ranked according to date of discovery within the assessment unit, in million barrels of oil (MMBO) for oil assessment units or billion cubic feet of gas (BCFG) for gas assessment units.

(22) Prob1 \% - charge probability, the probability for adequate petroleum charge for at least one untested cell equal to or larger than the minimum total recovery, somewhere in the assessment unit, having the potential to be added to reserves. Charge probability is given as a fractional value from 0 to 1.0 .

(23) Prob2 \% - rocks probability, the probability for adequate reservoirs, traps, and seals for at least one untested cell equal to or larger than the minimum total recovery, somewhere in the assessment unit, having the potential to be added to reserves. Rocks probability is given as a fractional value from 0 to 1.0 .

(24) Prob3 \% - timing probability, the probability for favorable geologic timing for at least one untested cell equal to or larger than the minimum total recovery, somewhere in the assessment unit, having the potential to be added to reserves. Timing probability is given as a fractional value from 0 to 1.0 .

(25) Geoprob \%-geologic probability, the product of charge, rocks, and timing probabilities. Geologic probability is given as a fractional value from 0 to 1.0.

(26) TAAmin a-minimum total assessment-unit area, the estimated minimum (F100) area of the assessment unit. The area is given in acres.

(27) TAAmod a-mode of total assessment-unit area, the estimated modal area of the assessment unit. The area is given in acres.

(28) TAAmax a-maximum total assessment-unit area, the estimated maximum (F0) area of the assessment unit. The area is given in acres.

(29) TAAmean a-mean of total assessment-unit area, the calculated mean area of the assessment unit. The area is given in acres.

(30) CAmin a-minimum area per cell of untested cells with potential, the estimated minimum (F100) area per cell of untested cells having the potential for additions to reserves in the assessment unit. This area is equivalent to the drainage area of wells. This area is given in acres.

(31) CAmod a-mode of area per cell of untested cells with potential, the estimated modal area per cell of untested cells having the potential for additions to reserves in the assessment unit. This area is equivalent to the drainage area of wells. This area is given in acres.

(32) CAmax a-maximum area per cell of untested cells with potential, the estimated maximum (F0) area per cell of untested cells having the potential for additions to reserves in the assessment unit. This area is equivalent to the drainage area of wells. This area is given in acres.

(33) CAmean a-mean area per cell of untested cells with potential, the calculated mean area per cell of untested cells having the potential for additions to reserves in the assessment unit. This area is equivalent to the drainage area of wells. This area is given in acres.

(34) CAminmn a-minimum calculated mean of the area per cell of untested cells with potential, the minimum uncertainty of the calculated mean area per cell of untested cells having the potential for additions to reserves in the assessment unit. This area is equivalent to the drainage area of wells. This area is given in acres.

(35) CAmaxmn a-maximum calculated mean of the area per cell of untested cells with potential, the maximum uncertainty of the calculated mean area per cell of untested cells having the potential for additions to reserves in the assessment unit. This area is equivalent to the drainage area of wells. This area is given in acres.

(36) TAAUmin \%-estimated minimum (F100) percentage of the total assessment-unit area that is untested.

(37) TAAUmod \%-estimated modal percentage of the total assessment-unit area that is untested.

(38) TAAUmax \%-estimated maximum (F0) percentage of the total assessment-unit area that is untested.

(39) TAAUmean \%-calculated mean percentage of the total assessment-unit area that is untested.

(40) UAAPmin \%—estimated minimum (F100) percentage of the untested area in the assessment unit having the potential for additions to reserves.

(41) UAAPmod \%-estimated modal percentage of the untested area in the assessment unit having the potential for additions to reserves.

(42) UAAPmax \%-estimated maximum (F0) percentage of the untested area in the assessment unit having the potential for additions to reserves.

(43) UAAPmean \%-calculated mean percentage of the untested area in the assessment unit having the potential for additions to reserves.

(44) RminMMBBCF-estimated minimum (F100) total recovery per cell for untested cells in the assessment unit having the potential for additions to reserves. This volume is given as million barrels of oil (MMBO) for oil assessment units and billion cubic feet of gas (BCFG) for gas assessment units.

(45) RmedMMBBCF-estimated median (F50) total recovery per cell for untested cells in the assessment unit having the potential for additions to reserves. This volume is given as million barrels of oil (MMBO) for oil 
assessment units and billion cubic feet of gas (BCFG) for gas assessment units.

(46) RmaxMMBBCF_-estimated maximum (F0) total recovery per cell for untested cells in the assessment unit having the potential for additions to reserves. This volume is given as million barrels of oil (MMBO) for oil assessment units and billion cubic feet of gas (BCFG) for gas assessment units.

(47) RmnMMBBCF_ - calculated mean total recovery per cell for untested cells in the assessment unit having the potential for additions to reserves. This volume is given as million barrels of oil (MMBO) for oil assessment units and billion cubic feet of gas (BCFG) for gas assessment units.

(48) $\mathrm{GminCF} / \mathrm{B}$ - estimated minimum (F100) gas-to-oil ratio (GOR), in cubic feet of gas per barrel of oil (CFG/BO), of untested cells equal to or larger than the minimum total recovery in oil assessment units.

(49) GmodCF/B — estimated mode of gas-to-oil ratio (GOR), in cubic feet of gas per barrel of oil (CFG/BO), of untested cells equal to or larger than the minimum total recovery in oil assessment units.

(50) GmaxCF/B — estimated maximum (F0) gas-to-oil ratio (GOR), in cubic feet of gas per barrel of oil (CFG/BO), of untested cells equal to or larger than the minimum total recovery in oil assessment units.

(51) NminB/MMCF_estimated minimum (F100) natural gas liquids (NGL) to gas ratio, in barrels of natural gas liquids per million cubic feet of gas (BNGL/MMCFG), of untested cells equal to or larger than the minimum total recovery in oil assessment units.

(52) NmodB/MMCF- estimated mode of natural gas liquids (NGL) to gas ratio, in barrels of natural gas liquids per million cubic feet of gas (BNGL/MMCFG), of untested cells equal to or larger than the minimum total recovery in oil assessment units.

(53) NmaxB/MMCF_estimated maximum (F0) natural gas liquids (NGL) to gas ratio, in barrels of natural gas liquids per million cubic feet of gas (BNGL/MMCFG), of untested cells equal to or larger than the minimum total recovery in oil assessment units.

(54) LminB/MMCF_estimated minimum (F100) liquids (oil plus natural gas liquids) to gas ratio (LGR), in barrels of liquids per million cubic feet of gas (BNGL/MMCFG), of untested cells equal to or larger than the minimum total recovery in gas assessment units.

(55) LmodB/MMCF_-estimated mode of liquids (oil plus natural gas liquids) to gas ratio (LGR), in barrels of liquids per million cubic feet of gas (BNGL/MMCFG), of untested cells equal to or larger than the minimum total recovery in gas assessment units.

(56) $\mathrm{LmaxB} / \mathrm{MMCF}$ — estimated maximum (F0) liquids (oil plus natural gas liquids) to gas ratio (LGR), in barrels of liquids per million cubic feet of gas (BNGL/MMCFG), of untested cells equal to or larger than the minimum total recovery in gas assessment units.
(57) APImin deg — estimated minimum (F100) API gravity, in degrees, of oil in untested cells in oil assessment units.

(58) APImod deg-estimated mode of API gravity, in degrees, of oil in untested cells in oil assessment units.

(59) APImax deg-estimated maximum (F0) API gravity, in degrees, of oil in untested cells in oil assessment units.

(60) Smin \%-estimated minimum (F100) sulfur content, in percent, of oil in untested cells in oil assessment units.

(61) Smod \%-estimated mode of sulfur content, in percent, of oil in untested cells in oil assessment units.

(62) Smax \%-estimated maximum (F0) sulfur content, in percent, of oil in untested cells in oil assessment units.

(63) ODmin m-estimated minimum (F100) drilling depth, in meters, of oil in untested cells in oil assessment units.

(64) ODf75 m-estimated 75th fractile (F75) of drilling depth, in meters, of oil in untested cells in oil assessment units.

(65) ODmod $\mathrm{m}$ - estimated mode of drilling depth, in meters, of oil in untested cells in oil assessment units.

(66) ODf25 m-estimated 25th fractile (F25) drilling depth, in meters, of oil in untested cells in oil assessment units.

(67) ODmax m-estimated maximum (F0) drilling depth, in meters, of oil in untested cells in oil assessment units.

(68) OWDmin m-estimated minimum (F100) water depth, in meters, of oil in untested cells in oil assessment units (ocean, bays, or lakes; if applicable).

(69) OWDmod m-estimated mode of water depth, in meters, of oil in untested cells in oil assessment units (ocean, bays, or lakes; if applicable).

(70) OWDmax m-estimated maximum (F0) water depth, in meters, of oil in untested cells in oil assessment units (ocean, bays, or lakes; if applicable).

(71) IGmin \%-estimated minimum (F100) inert gas content, in percent, of gas in untested cells in gas assessment units (nitrogen, helium, etc.).

(72) IGmod \%—estimated mode of inert gas content, in percent, of gas in untested cells in gas assessment units (nitrogen, helium, etc.).

(73) IGmax \%-estimated maximum (F0) inert gas content, in percent, of gas in untested cells in gas assessment units (nitrogen, helium, etc.).

(74) $\mathrm{CO}_{2}$ min \%-estimated minimum (F100) carbon dioxide content, in percent, of gas in untested cells in gas assessment units.

(75) $\mathrm{CO}_{2} \bmod \%$ - estimated mode of carbon dioxide content, in percent, of gas in untested cells in gas assessment units.

(76) $\mathrm{CO}_{2} \max \%$ - estimated maximum (F0) carbon dioxide content, in percent, of gas in untested cells in gas assessment units.

(77) $\mathrm{H}_{2} \mathrm{Smin} \%$ - estimated minimum (F100) hydrogen sulfide content, in percent, of gas in untested cells in gas assessment units.

(78) $\mathrm{H}_{2} \mathrm{Smod} \%$ - estimated mode of hydrogen sulfide content, in percent, of gas in untested cells in gas assessment units.

(79) $\mathrm{H}_{2} \mathrm{Smax} \%$ - estimated maximum (F0) hydrogen sulfide content, in percent, of gas in untested cells in gas 
assessment units.

(80) HVmin btu—estimated minimum (F100) heating value of gas, in British Thermal Units, of gas in untested cells in gas assessment units.

(81) HVmod btu-estimated mode of heating value of gas, in British Thermal Units, of gas in untested cells in gas assessment units.

(82) HVmax btu-estimated maximum (F0) heating value of gas, in British Thermal Units, of gas in untested cells in gas assessment units.

(83) GDmin m-estimated minimum (F100) drilling depth, in meters, of gas in untested cells in gas assessment units.

(84) GDf25 m-estimated 25th fractile (F25) drilling depth, in meters, of gas in untested cells in gas assessment units.

(85) GDmod m-estimated mode of drilling depth, in meters, of gas in untested cells in gas assessment units.

(86) GDf25 m-estimated 25th fractile (F25) drilling depth, in meters, of gas in untested cells in gas assessment units.

(87) GDmax m-estimated maximum (F0) drilling depth, in meters, of gas in untested cells in gas assessment units.

(88) GWDmin m-estimated minimum (F100) water depth, in meters, of gas in untested cells in gas assessment units (ocean, bays, or lakes; if applicable).

(89) GWDmod m-estimated mode of water depth, in meters, of gas in untested cells in gas assessment units (ocean, bays, or lakes; if applicable).

(90) GWDmax m-estimated maximum (F0) water depth, in meters, of gas in untested cells in gas assessment units (ocean, bays, or lakes; if applicable).

(91) FSRmean \%-estimated mean future success ratio, as percent.

(92) FSRmin \%—estimated minimum (F100) future success ratio, as percent.

(93) FSRmod \% — estimated mode of future success ratio, as percent.

(94) FSRmax \%-estimated maximum (F100) future success ratio, as percent.

(95) HSR \%-historical success ratio, as percent.

(96) TWCP_-typical well-completion practice.

(97) FWTS - fraction of wells drilled that are typically stimulated, as decimal fraction.

(98) PST — predominant type of stimulation.

(99) FHW-fraction of wells drilled that are horizontal, as decimal fraction.

The ins\#\#\#\#.tab table contains input data from the Seventh Approximation Data Forms for Conventional Assessment Units used in this assessment and provided in the c\#\#\#\#\#\#.pdf files. Cells are left blank if data are unavailable. This table contains 75 columns. Data columns are:

(1) Date-date of assessment.

(2) Geol-assessing geologist's name.

(3) Regno-region code number.

(4) Reg-region name.

(5) Provno-province code number.

(6) Prov-province name.
(7) TPSno- -total petroleum system code number.

(8) TPS - total petroleum system name.

(9) AUno_-assessment-unit code number.

(10) AU-assessment-unit name.

(11) Data - data sources used to aid in completing the datainput form.

(12) Comm-primary commodity type in the assessment unit, based on the gas-to-oil ratio of the petroleum endowment, which includes both the discovered and undiscovered petroleum. An assessment unit is characterized as being oil prone if the gas-to-oil ratio is less than 20,000 cubic feet of gas per barrel of oil; otherwise, it is gas prone.

(13) Minsize MMB - minimum accumulation size considered for assessment, in million barrels of oil equivalent (MMBOE).

(14) Numoil—number of oil accumulations equal to or larger than the minimum accumulation size discovered in the assessment unit.

(15) Numgas — number of gas accumulations equal to or larger than the minimum accumulation size discovered in the assessment unit.

(16) AUM-assessment-unit maturity, the exploration maturity of the assessment unit. Assessment-unit maturity is classified as "established" if more than 13 accumulations exceeding minimum size have been discovered, "frontier" if 1 to 13 accumulations exceeding minimum size have been discovered, or "hypothetical" if no accumulations exceeding minimum size have been discovered.

(17) MedO1MMB - median size of the set of discovered oil accumulations that constitute the first one-third or onehalf of the total number of oil accumulations ranked according to date of discovery within the assessment unit, in million barrels of oil (MMBO). This size is derived from known oil volumes that were adjusted upward to account for estimated future reserve growth.

(18) MedO2MMB - median size of the set of discovered oil accumulations that constitute the second one-third or one-half of the total number of oil accumulations ranked according to date of discovery within the assessment unit, in million barrels of oil (MMBO). This size is derived from known oil volumes that were adjusted upward to account for estimated future reserve growth.

(19) MedO3MMB - median size of the set of discovered oil accumulations that constitute the third one-third of the total number of oil accumulations ranked according to date of discovery within the assessment unit, in million barrels of oil (MMBO). This size is derived from known oil volumes that were adjusted upward to account for estimated future reserve growth.

(20) MedG1BCF - median size of the set of discovered gas accumulations that constitute the first one-third or one-half of the total number of gas accumulations ranked according to date of discovery within the 
assessment unit, in billion cubic feet of gas (BCFG). This size is derived from known gas volumes that were adjusted upward to account for estimated future reserve growth.

(21) MedG2BCF - median size of the set of discovered gas accumulations that constitute the second one-third or one-half of the total number of gas accumulations ranked according to date of discovery within the assessment unit, in billion cubic feet of gas (BCFG). This size is derived from known gas volumes that were adjusted upward to account for estimated future reserve growth.

(22) MedG3BCF - median size of the set of discovered gas accumulations that constitute the third one-third of the total number of gas accumulations ranked according to date of discovery within the assessment unit, in billion cubic feet of gas (BCFG). This size is derived from known gas volumes that were adjusted upward to account for estimated future reserve growth.

(23) Prob1\%—charge probability, the probability for adequate petroleum charge for at least one undiscovered accumulation equal to or larger than the minimum accumulation size, somewhere in the assessment unit, having the potential to be added to reserves. Charge probability is given as a fractional value from 0 to 1.0.

(24) Prob2\%-rocks probability, the probability for adequate reservoirs, traps, and seals for at least one undiscovered accumulation equal to or larger than the minimum accumulation size, somewhere in the assessment unit, having the potential to be added to reserves. Rocks probability is given as a fractional value from 0 to 1.0.

(25) Prob3\%-timing probability, the probability for favorable geologic timing for at least one undiscovered accumulation equal to or larger than the minimum accumulation size, somewhere in the assessment unit, having the potential to be added to reserves. Timing probability is given as a fractional value from 0 to 1.0.

(26) Geoprob \%-geologic probability, the product of charge, rocks, and timing probabilities. Geologic probability is given as a fractional value from 0 to 1.0 .

(27) NOmin—estimated minimum (F100) number of undiscovered oil accumulations equal to or larger than the minimum accumulation size in the assessment unit.

(28) NOmod-estimated mode of number of undiscovered oil accumulations equal to or larger than the minimum accumulation size in the assessment unit.

(29) NOmax - estimated maximum (F0) number of undiscovered oil accumulations equal to or larger than the minimum accumulation size in the assessment unit.

(30) NGmin—estimated minimum (F100) number of undiscovered gas accumulations equal to or larger than the minimum accumulation size in the assessment unit.

(31) NGmod-estimated mode of number of undiscovered gas accumulations equal to or larger than the minimum accumulation size in the assessment unit.

(32) NGmax — estimated maximum (F0) number of undiscovered gas accumulations equal to or larger than the minimum accumulation size in the assessment unit.

(33) SOminMMB — estimated minimum (F100) size, in million barrels of oil (MMBO), of undiscovered oil accumulations in the assessment unit.

(34) SOmedMMB - estimated median (F50) size, in million barrels of oil (MMBO), of undiscovered oil accumulations in the assessment unit.

(35) SOmaxMMB — estimated maximum (F0) size, in million barrels of oil (MMBO), of undiscovered oil accumulations in the assessment unit.

(36) SGminBCF-estimated minimum (F100) size, in billion cubic feet of gas (BCFG), of undiscovered gas accumulations in the assessment unit.

(37) SGmedBCF—estimated median (F50) size, in billion cubic feet of gas (BCFG), of undiscovered gas accumulations in the assessment unit.

(38) SGmaxBCF-estimated maximum (F0) size, in billion cubic feet of gas (BCFG), of undiscovered gas accumulations in the assessment unit.

(39) GminCF/B — estimated minimum (F100) gas-to-oil ratio (GOR), in cubic feet of gas per barrel of oil (CFG/BO), of undiscovered oil accumulations equal to or larger than the minimum accumulation size in the assessment unit.

(40) GmodCF/B — estimated mode of gas-to-oil ratio (GOR), in cubic feet of gas per barrel of oil (CFG/BO), of undiscovered oil accumulations equal to or larger than the minimum accumulation size in the assessment unit.

(41) GmaxCF/B — estimated maximum (F0) gas-to-oil ratio (GOR), in cubic feet of gas per barrel of oil (CFG/BO), of undiscovered oil accumulations equal to or larger than the minimum accumulation size in the assessment unit.

(42) NminB/MMCF-estimated minimum (F100) natural gas liquids (NGL) to gas ratio, in barrels of natural gas liquids per million cubic feet of gas (BNGL/MMCFG), of undiscovered oil accumulations equal to or larger than the minimum accumulation size in the assessment unit.

(43) NmodB/MMCF — estimated mode of natural gas liquids (NGL) to gas ratio, in barrels of natural gas liquids per million cubic feet of gas (BNGL/MMCFG), of undiscovered oil accumulations equal to or larger than the minimum accumulation size in the assessment unit.

(44) NmaxB/MMCF-estimated maximum (F0) natural gas liquids (NGL) to gas ratio, in barrels of natural gas liquids per million cubic feet of gas (BNGL/MMCFG), of undiscovered oil accumulations equal to or larger than the minimum accumulation size in the assessment unit.

(45) LminB/MMCF—estimated minimum (F100) liquids (oil plus natural gas liquids) to gas ratio (LGR), in barrels of liquids per million cubic feet of gas (BL/MMCFG), of undiscovered gas accumulations equal to or larger than the minimum accumulation size in the assessment unit.

(46) LmodB/MMCF - estimated mode of liquids (oil plus natural gas liquids) to gas ratio (LGR), in barrels of liquids per million cubic feet of gas (BL/MMCFG), of undiscovered gas accumulations equal to or larger than the minimum accumulation size in the assessment unit. 
(47) LmaxB/MMCF—estimated maximum (F0) liquids (oil plus natural gas liquids) to gas ratio (LGR), in barrels of liquids per million cubic feet of gas (BL/MMCFG), of undiscovered gas accumulations equal to or larger than the minimum accumulation size in the assessment unit.

(48) APImin deg-estimated minimum (F100) API gravity, in degrees, of oil in undiscovered oil accumulations in the assessment unit.

(49) APImod deg—estimated mode of API (American Petroleum Institute) gravity, in degrees, of oil in undiscovered oil accumulations in the assessment unit.

(50) APImax deg—estimated maximum (F0) API gravity, in degrees, of oil in undiscovered oil accumulations in the assessment unit.

(51) Smin \%-estimated minimum (F100) sulfur content, in percent, of oil in undiscovered oil accumulations in the assessment unit.

(52) Smod \%-estimated mode of sulfur content, in percent, of oil in undiscovered oil accumulations in the assessment unit.

(53) Smax \%-estimated maximum (F0) sulfur content, in percent, of oil in undiscovered oil accumulations in the assessment unit.

(54) ODmin m-estimated minimum (F100) drilling depth, in meters, of oil in untested cells in oil assessment units.

(55) ODf75 m-estimated 75th fractile (F75) of drilling depth, in meters, of oil in untested cells in oil assessment units.

(56) ODmod $\mathrm{m}$ - estimated mode of drilling depth, in meters, of oil in untested cells in oil assessment units.

(57) ODf $25 \mathrm{~m}$-estimated 25th fractile (F25) drilling depth, in meters, of oil in untested cells in oil assessment units.

(58) ODmax m-estimated maximum (F0) drilling depth, in meters, of oil in untested cells in oil assessment units.

(59) OWDmin m-estimated minimum (F100) water depth, in meters, of oil in untested cells in oil assessment units (ocean, bays, or lakes; if applicable).

(60) OWDmod m — estimated mode of water depth, in meters, of oil in untested cells in oil assessment units (ocean, bays, or lakes; if applicable).

(61) OWDmax m-estimated maximum (F0) water depth, in meters, of oil in untested cells in oil assessment units (ocean, bays, or lakes; if applicable).

(62) IGmin \%-estimated minimum (F100) inert gas content, in percent, of gas in untested cells in gas assessment units (nitrogen, helium, etc.).

(63) IGmod \% - estimated mode of inert gas content, in percent, of gas in untested cells in gas assessment units (nitrogen, helium, etc.).

(63) IGmax \% - estimated maximum (F0) inert gas content, in percent, of gas in untested cells in gas assessment units (nitrogen, helium, etc.).

(65) $\mathrm{CO}_{2}$ min \%-estimated minimum (F100) carbon dioxide content, in percent, of gas in untested cells in gas assessment units.

(66) $\mathrm{CO}_{2} \bmod \%$ - estimated mode of carbon dioxide content, in percent, of gas in untested cells in gas assessment units.
(67) $\mathrm{CO}_{2} \max \%$ - estimated maximum (F0) carbon dioxide content, in percent, of gas in untested cells in gas assessment units.

(68) $\mathrm{H}_{2} \mathrm{Smin} \%$ - estimated minimum (F100) hydrogen sulfide content, in percent, of gas in untested cells in gas assessment units.

(69) $\mathrm{H}_{2} \mathrm{Smod} \%$ - estimated mode of hydrogen sulfide content, in percent, of gas in untested cells in gas assessment units.

(70) $\mathrm{H}_{2} \mathrm{Smax} \%$ - estimated maximum (F0) hydrogen sulfide content, in percent, of gas in untested cells in gas assessment units.

(71) GDmin m-estimated minimum (F100) drilling depth, in meters, of gas in untested cells in gas assessment units.

(72) GDf25 m-estimated 25th fractile (F25) drilling depth, in meters, of gas in untested cells in gas assessment units.

(73) GDmod m - estimated mode of drilling depth, in meters, of gas in untested cells in gas assessment units.

(74) GDf25 m-estimated 25th fractile (F25) drilling depth, in meters, of gas in untested cells in gas assessment units.

(75) GDmax m-estimated maximum (F0) drilling depth, in meters, of gas in untested cells in gas assessment units.

(76) GWDmin m-estimated minimum (F100) water depth, in meters, of gas in untested cells in gas assessment units (ocean, bays, or lakes; if applicable).

(77) GWDmod m-estimated mode of water depth, in meters, of gas in untested cells in gas assessment units (ocean, bays, or lakes; if applicable).

(78) GWDmax m-estimated maximum (F0) water depth, in meters, of gas in untested cells in gas assessment units (ocean, bays, or lakes; if applicable).

Data in the kvol\#\#\#\#.tab table are derived from a commercially purchased database (NRG Associates, 2005) and are current through 2003. This table contains 15 columns. Blank cells represent no data. Data columns for these files are:

(1) Code-assessment-unit code number.

(2) Name - assessment-unit name.

(3) Numres - number of reported reservoirs in the assessment unit.

(4) CUMOIL MMB - cumulative production of oil from the reported reservoirs in the assessment unit. This volume is in million barrels of oil (MMBO).

(5) REMOIL MMB - remaining oil reserves in the reported reservoirs in the assessment unit. This volume is in million barrels of oil (MMBO).

(6) KROIL MMB - known recoverable oil volume (cumulative production plus remaining reserves) from the reported reservoirs in the assessment unit. This volume is in million barrels of oil (MMBO).

(7) CUMGAS BCF-cumulative production of natural gas from the reported reservoirs in the assessment unit. This volume is in billion cubic feet of gas (BCFG).

(8) REMGAS BCF-remaining natural gas reserves in the reported reservoirs in the assessment unit. This volume is in billion cubic feet of gas (BCFG). 
(9) KRGAS BCF — known recoverable natural gas volume (cumulative production plus remaining reserves) from the reported reservoirs in the assessment unit. This volume is in billion cubic feet of gas (BCFG).

(10) CUMNGL MMB - cumulative production of natural gas liquids (NGL) from the reported reservoirs in the assessment unit. This volume is in million barrels of natural gas liquids (MMBNGL).

(11) REMNGL MMB - remaining natural gas liquids (NGL) reserves in the reported reservoirs in the assessment unit. This volume is in million barrels of natural gas liquids (MMBNGL).

(12) KRNGL MMB - known recoverable natural gas liquids (NGL) volume (cumulative production plus remaining reserves) from the reported reservoirs in the assessment unit. This volume is in million barrels of natural gas liquids (MMBNGL).

(13) CUMPET MMB - cumulative production of petroleum (oil, gas, and NGL) from the reported reservoirs in the assessment unit. This volume is in million barrels of oil equivalent (MMBOE).

(14) REMPET MMB - remaining petroleum (oil, gas, and NGL) reserves in the reported reservoirs in the assessment unit. This volume is in million barrels of oil equivalent (MMBOE).

(15) KRPET MMB - known recoverable petroleum (oil, gas, and NGL) volume (cumulative production plus remaining reserves) from the reported reservoirs in the assessment unit. This volume is in million barrels of oil equivalent (MMBOE).

\section{Summary Tables}

The c\#\#\#\#\#.pdf and u\#\#\#\#\#\#.pdf files are copies of the completed input data forms used in the assessment process. The c\#\#\#\#\#.pdf files contain the Seventh Approximation Data Forms for Conventional Assessment Units. The u\#\#\#\#\#\#. pdf files contain the FORSPAN Assessment Model for Continuous Accumulations-Basic Input Data Form. These data are defined in the inf\#\#\#\#.tab and ins\#\#\#\#.tab sections of this report.

The d\#\#\#\#\#\#.pdf files contain three tables of known and grown petroleum volumes in an assessment unit as a whole and in terms of discovery history. Grown field sizes are defined as known accumulation sizes that were adjusted upward to account for estimated future reserve growth. NA means not applicable and is shown in place of volumes for which only one field is present to protect the proprietary nature of the data.

\section{Graphical Data}

The fp\#\#\#\#\#\#.pdf files contain graphs of input data and estimated petroleum resource volumes for continuous assessment units. The data are defined in the inf\#\#\#.tab and vol\#\#\#\#.tab sections of this report. The graphs contained in these files are derived from a report generated by a commercial software package. The quality of these preformatted graphs, therefore, does not necessarily meet USGS editorial standards.

The em\#\#\#\#\#.pdf files contain graphs of input data and estimated petroleum resource volumes for conventional assessment units. The data are defined in the ins\#\#\#\#.tab and vol\#\#\#\#.tab sections of this report. The graphs contained in these files are derived from a report generated by a commercial software package. The quality of these preformatted graphs, therefore, does not necessarily meet USGS editorial standards.

The g\#\#\#\#\#.pdf and k\#\#\#\#\#.pdf files contain graphs of exploration and discovery data for conventional assessment units. The volumetric data are defined in the kvol\#\#\#\#.tab sections of this report. To protect the proprietary nature of the data, these files are not provided if the total number of accumulations in the assessment unit that are greater than or equal to the specified minimum size is less than four.

Two sets of exploration-activity and discovery-history graphs are provided for each of the assessment units, one set showing known field sizes (cumulative production plus remaining reserves) and the other showing field sizes that were adjusted to compensate for potential reserve growth that may occur in the next 30 years (labeled "grown"). Within each set of graphs, oil fields and gas fields are treated separately. The graphs include:

- Cumulative Number of New-Field Wildcat Wells vs. Drilling-Completion Year

- Number of New-Field Wildcat Wells vs. Drilling-Completion Year

- Oil- or Gas-Accumulation Size (MMBO or BCFG) vs. Oil- or Gas-Accumulation Rank by Size (With Respect to Discovery Halves or Thirds)

- Number of Oil or Gas Accumulations vs. Oil- or GasAccumulation Size Classes (MMBO or BCFG) (With Respect to Discovery Halves or Thirds)

- Volume of Oil or Gas (MMBO or BCFG) vs. Oil- or Gas-Accumulation Size Classes (MMBO or BCFG)

- Oil- or Gas-Accumulation Size (MMBO or BCFG) vs. Accumulation-Discovery Year

- Oil- or Gas-Accumulation Size (MMBO or BCFG) vs. Cumulative Number of New-Field Wildcat Wells

- Cumulative Oil or Gas Volume (MMBO or BCFG) vs. Accumulation-Discovery Year

- Cumulative Oil or Gas Volume (MMBO or BCFG) vs. Cumulative Number of New-Field Wildcat Wells

- Cumulative Number of Oil or Gas Accumulations vs. 
Accumulation-Discovery Year

- Cumulative Number of Oil or Gas Accumulations vs. Cumulative Number of New-Field Wildcat Wells

- Reservoir Depth, Oil or Gas Accumulations (ft), vs. Accumulation-Discovery Year

- Reservoir Depth, Oil or Gas Accumulations (ft) vs. Cumulative Number of New-Field Wildcat Wells

- Gas/Oil, Oil Accumulations (CFG/BO) vs. Mean Reservoir Depth (ft)

- NGL/Gas, Oil Accumulations (BNGL/MMCFG) vs. Mean Reservoir Depth (ft)

- Liquids/Gas, Gas Accumulations (BL/MMCFG) vs. Mean Reservoir Depth (ft)

- Number of Reservoirs in Oil Accumulations vs. API Gravity (Degrees)

Graphs are not provided if data are insufficient or do not exist, Therefore, not all graphs are included in all files.

\section{File List}

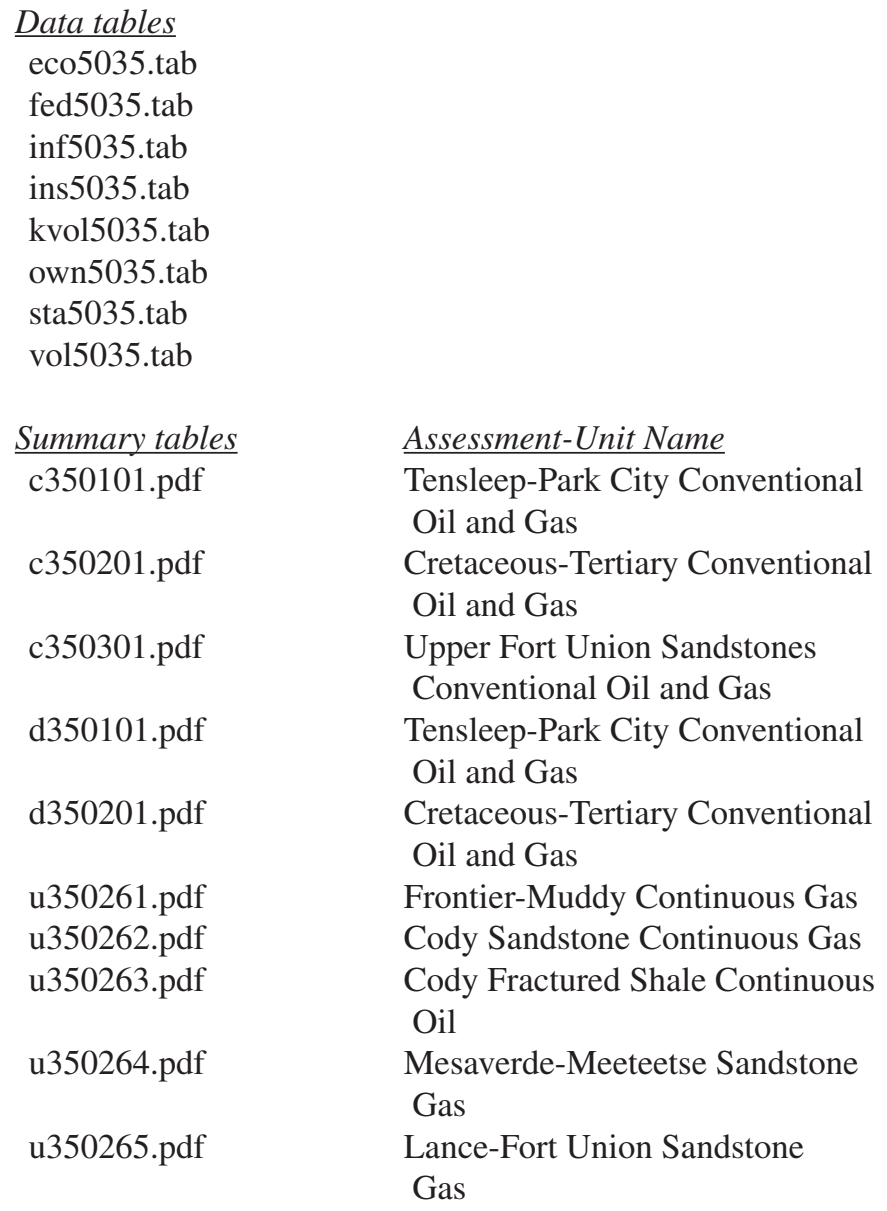

u350281.pdf
u350282.pdf
u350283.pdf
u350361.pdf

Graphs

em350101.pdf

em350201.pdf

em350301.pdf

fp350261.pdf

fp350262.pdf

fp350264.pdf

fp350265.pdf

fp350281.pdf

fp350282.pdf

fp350283.pdf

g350101.pdf

g350201.pdf

k350101.pdf

k350201.pdf
Mesaverde Coalbed Gas Meeteetse Coalbed Gas Fort Union Coalbed Gas Waltman Fractured Shale Continuous Oil

Assessment-Unit Name
Tensleep-Park City
Conventional Oil and Gas
Cretaceous-Tertiary
Conventional Oil and Gas
Upper Fort Union Sandstones
Conventional Oil and Gas
Frontier-Muddy Continuous Gas
Cody Sandstone Continuous Gas
Mesaverde-Meeteetse
Sandstone Gas
Lance-Fort Union Sandstone
Gas
Mesaverde Coalbed Gas
Meeteetse Coalbed Gas
Fort Union Coalbed Gas
Tensleep-Park City
Conventional Oil and Gas
Cretaceous-Tertiary
Conventional Oil and Gas
Tensleep-Park City
Conventional Oil and Gas
Cretaceous-Tertiary
Conventional Oil and Gas

\section{References Cited}

IHS Energy Group, 2005a [includes data current as of December 2005], PI/Dwights Plus US Production Data: IHS Energy Group; database available from IHS Energy Group, 15 Inverness Way East, D205, Englewood, CO 80112, U.S.A.

IHS Energy Group, 2005b [includes data current as of December 2005], PI/Dwights Plus US Well Data: IHS Energy Group; database available from IHS Energy Group, 15 Inverness Way East, D205, Englewood, CO 80112, U.S.A.

NRG Associates, 2005 [includes data current as of December 2003], The significant oil and gas fields of the United States: NRG Associates, Inc.; database available from NRG Associates, Inc., P.O. Box 1655, Colorado Springs, CO 80901, U.S.A

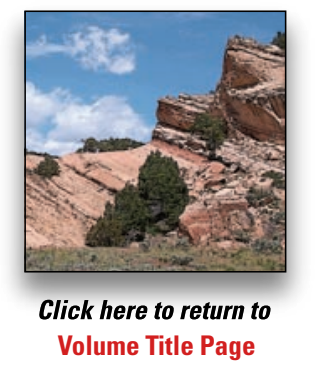

